\title{
Exploring EFL Students' Gaming Experience in Acquiring Second Language Vocabulary
}

\author{
Resna Suci Nurfalah \\ Universitas Pendidikan Indonesia \\ Bandung, Indonesia \\ resnasucinurfalah@upi.edu
}

\begin{abstract}
How students acquire a second language (L2) has been varied due to the development of information and communications technology (ICT). Different digital technologies, especially video games, which are used to assist students in acquiring language have been examined by researchers. However, studies exploring EFL students' gaming experience in acquiring a second language (L2) vocabulary is sparsely investigated. For that reason, this study aims at exploring how EFL students' gaming experience assists the students in acquiring their second language (L2) vocabulary. The data of this study were gained from EFL students' experience. Four EFL students were interviewed, and the data from the interview were analyzed through thematic analysis. Several of the initial questions given to the EFL students were used to stimulate the students to begin to tell their experience in playing games. Then, other questions were delivered to explore more about the story that the students have already told. The results of this study indicated that the games, particularly online games, have the potential to assist EFL students in acquiring second language (L2) vocabulary. Several principal reasons related to how games assist the students in acquiring new vocabulary emerged in this study. Pedagogically, this study contributes to the strategy of vocabulary teaching and learning which hopefully can be beneficial for EFL students and teachers.
\end{abstract}

Keywords: EFL students, gaming experience, L2 vocabulary acquisition, video games

\section{INTRODUCTION}

\subsection{Background}

Vocabulary plays a crucial role in teaching and learning any language. It is the basis of language which is crucial to be learned by language learners (Ashraf, Motlagh, \& Salami, 2014). Vocabulary is an important element that links the major language skills including speaking, reading, listening and writing in a foreign language (Huyen \& Nga, 2003). Having a rich vocabulary can be a gate for the learners to master their foreign language. Further, vocabulary plays a pivotal part in learners' language learning and also in their language proficiency since it can affect how well they listen, speak, write and read (Renandya \& Richards, 2002). Lack of vocabulary can be a serious problem when learners need to practice their foreign language directly with the native speaker of that language. For those reasons, vocabulary should be regarded as one of the essential aspects of foreign language teaching and learning, and it should be given much attention in TEFL practices. However, in many regions, vocabulary teaching and learning seems to be neglected in TEFL (Ashraf et al., 2014 Asyiah, 2017; Huyen \& Nga, 2003). Moreover, both students and teachers have experienced that teaching and learning vocabulary is fairly boring yet challenging (Epstein, 2007; Folse \& Briggs, 2004; Read, 2000). Many teachers were unfamiliar with vocabulary instructional strategies and faced dilemmas on how to introduce new vocabulary in their daily teaching practices (Gilford, 2016). As an educator, the teacher needs to facilitate learners to learn vocabulary in an effective and interesting strategy. There are at least three aspects in which learners need to acquire vocabulary which is (1) knowing its form, (2) knowing its meaning, and (3) knowing its use (Nation, 2000). Thus, someone is said to acquire vocabulary when they pronounce and spell the word accurately, know the meaning and know in what context they can use the word.

Recently, the development of information and communications technology (ICT) has given a great impact on the ways and strategies of teaching and learning a foreign language, particularly in the second language (L2) vocabulary acquisition. Moreover, the internet has given the learners access to learning many things in their preferences. Many kinds of games have been used to facilitate language learning. There are at least two types of games which are the game which is made to learn the language and the game which is not actually for learning. Quantitative researches related to the effect of particular games on vocabulary have already done by many researchers. However, the qualitative study which reveals students' experience in acquiring second language (L2) vocabulary through a game is sparsely investigated. Thus, this study aims at exploring how EFL students' gaming experience assists the students in acquiring their second language (L2) vocabulary.

\subsection{Games and Language Learning}

Many terms came up as the trend of games to facilitate learning became greater. One popular term is gamification. Gamification enhances the learning of second language skills, creates meaningful experiences and motivates collaboration and instruction, but it needs to align clear learning objectives and to have formal assessment criteria. Flores (2015) clearly defined the concept of gamification, simply it is the use of the game in non-game contexts, and explored its roles in enhancing second language learning. Another term related to games that facilitate language learning is DGBLL. Cornillie, Thorne, and Desmet (2012) asserted that the terms of DGBLL were still 
debatable, but at least there were several elements which need to be considered in defining the essential aspect, which is game, in DGBLL, such as a problem to solve, competition, timing, etc. Learners' perception was another hot issue related to DGBLL which said that the kind of outcomes and goals valued by the learners are highly individual.

\section{METHOD}

\section{A. Research Design}

A descriptive case study was selected to investigate the EFL students' gaming experience in acquiring a second language (L2) vocabulary. This design provides an 'allencompassing method' for systematically describing a phenomenon within a real-life context, which is, in this case, the contribution of online games to the acquisition of students' English vocabulary (Yin, 2003).

\section{B. Respondents}

The respondents of this study were four EFL students of a university in Tasikmalaya, West Java, who have already played games for more than 5 years and still play the routine of the game in their daily life now. Various games played by the respondents could make the analysis of this study too broad, but the games they have played actually could be categorized as two types which were MOBA (Multiplayer Online Battle Arena) Game and Survival Game. Thus, those two types of games became the limitation of this study. Each respondent played the game daily with the range of playing duration from 40 minutes to 3 hours per day. All the games which they have played are in English.

\section{Instruments}

The researcher gave the participants freedom in choosing any issues they wanted to explore in their accounts. Besides, the researcher also explored several parts of the respondents' story or experience based on the story told by them. However, there were several questions guidelines used by the researcher to make sure that the storyline of the respondents is in the track. Here are several of the questions guideline used in this paper:

1. What game/s do you usually play?

2. When did you start playing the game/s?

3. How much time do you spend on playing game/s each day?

4. When did you realize that playing game/s enrich your vocabulary?

5. How do you learn new vocab from the game/s?

\section{Procedures}

The researcher did some steps to obtain the data. After getting approval from the EFL students to participate in this study voluntarily, the researcher explained the research overview and then discussed the technique of interview. The interviews were finally done through WhatsApp since it is flexible and efficient. All names presented in this study will be pseudonyms as S1, S2, S3, and S4.

\section{E. Data Analysis}

The data gained only from the semi-structured interview. Transcribed data from the interview were analyzed through thematic analysis. Thematic analysis is widely used in qualitative research, especially to analyze interviews (Judger, 2016). Thematic analysis is a method used for 'identifying, analyzing, and reporting patterns (themes) within the data (Clarke \& Braun, 2013). The data from the in-depth interview were transcribed and were analyzed. Then, they were coded and were reduced into themes to find out how the online games assist EFL students to acquire second language (L2) vocabulary.

\section{FINDINGS AND DISCUSSION}

There are three emerged themes in this study related to the reasons beyond how actually games, especially online games, assist EFL students in acquiring second language (L2) vocabulary; online games provide a subconscious learning experience in a particular context, online games provide various strategies to learn English so that EFL students acquire second language (L2) vocabulary in many ways, and online games motivate EFL students to learn new thing, especially learning new second language (L2) vocabulary.

\section{A. Students' Experience in Accessing Subconscious Learning through Online Games}

Initially, all of the students did not have any intention of learning English through games. When they were asked whether they realize or not that they learn English while they play games, they said that they play for pleasure, not for learning. For example, one student expressed:

At first, I do not realize that I learned something. But, when I did my English homework, I was a senior high school student at that time, I found several words that I have got from the games I played. At that time, I realized that playing games can enhance my vocabulary. (S4, Extract 1)

Extract 1 reveals a priori view on the subconscious learning experience provided by the games supporting the students to learn. They play games for fun, and it is good as they will be under a relaxed and pleasant environment which can lead them to learn better (Adriano, 2017; Huyen \& Nga, 2003). At a particular time, the students may realize that they learn new things, especially new vocabulary from the games. However, this situation does not change their intention in playing the games so that their consciousness will not change their feeling towards the games. As portrayed in the following extract:

Yes, I finally realize that I learn new vocabulary. I learn mostly from the pictures, yes, visualization, and context. Moreover, sometimes I look up a dictionary to know the meaning, but it's okay, I still play games and have fun. (S2, Extract 2)

Extract 2 highlights two main ideas which are students' consciousness in learning English vocabulary and context which is visualized in the games. Many researchers found that learning under a communicative naturalistic context may be favorable, and when it blends with the consciousness, particularly for an adult learner, it may be more beneficial and 
effective (Chaochun \& Lian, 2005). By playing the games, the EFL students also can position themselves as someone else or a character needed in the game since the game provide the context for them to imagine. Many studies reveal that words need to be learned in a context to avoid ambiguity and to make it meaningful. Putting words in context will give the students new vocabulary meaning, and it can lead to meaningfulness which will make it get into long term memory. Moreover, context can boost students' learning process (Cahyono \& Widiati, 2015). Context helps the student to make meanings (Merawati, 2003). As shown in extract 2, the student make meanings from the context given in the games, and the following extract supports this perception:

When I do not know the meaning, I usually use google translate or look up my dictionary, but sometimes I just guessing by taking a look into the context of the game. For example when there is a war, then I try to position myself as someone who needs to survive in a war. Yeah, I just try to comprehend the context, sometimes. (S3, Extract 3)

Both MOBA game and survival game provide the animation with audio and visualization which assist the students to portray the context in their imagination and to engage with the situation given. Therefore, subconscious learning experiences, even at a particular time they actually realize that they learn, and the context provided in the games assist the students to acquire the second language (L2) vocabulary. Even though they do not intend to learn, they finally realize that they learn something by playing games. Especially when they found new vocabulary in the games, and then they find it in a real-life situation, they recognize that games contribute to their language learning.

\section{B. Students' Experience in Involving Various Strategies in Learning English through Online Games}

Every learner has a unique learning preference, and this is the reason why there are many learning strategies we can find in literature. The results show that through games, the students can acquire a second language (L2) vocabulary in many ways depending on their preferences in learning new vocabulary. Sometimes they learned from the audio of the game which means they practice their listening and pronunciation, and they sometimes also learn from the visualization of the game which means that game provides them to read or to portray the vocabulary they have learned. Another strategy portrayed in the findings is repetition so that the students learn the vocabulary repeatedly supported by the context provided in the games which made them easy to remember. Related to this perception, two of the student said:

As I've said before, I learn mostly from the visualization of the game. For example, when I play Sky Rim, I was given a mission to hunt the wolf. Then, after finishing the mission, I was given a reward 'wolf pelt', then I took a look into its visualization, and yeah, I catch the meaning. Without the visualization, it would be hard for me to understand several terms in this game because mostly it's not a modern life portrayed in the game. Yes, I also learn how to pronounce the words from its audio. (S1, Extract 4)
I found the words several times, mostly the technical words in the games. It makes me remember because I found it again and again at several levels of the game. (S2, Extract 5)

Besides learning through various modes and strategies, the students also undergo several steps in acquiring the vocabulary through games. This is in line with a concept by Grauberg (1997) which proposed four stages in learning vocabulary; discrimination, understanding meaning, remembering, and consolidation and extension of meaning. At a very basic stage, discrimination, the students can differentiate the sounds and letters of similar words. All of the students are engaged in this stage. They said that they learn how to pronounce new vocabulary by listening to the audio in the game, as shown in the extract 4 , and also remember how the word is written or spelled by looking at how it is written. Generally, the online game provides these two strategies to facilitate the students in acquiring a second language (L2) vocabulary. In the stage of understanding the meaning, the students can understand the concept of foreign vocabulary so that they can explain it to others. All of the students are also engaged in this stage. The context which is supported by the picture, animation, narration or description, character, and other visualization plays a great role in shaping students' understanding of the vocabulary. They believed that their understanding of the vocabulary which they have learned from the game is influenced by the quality of animation or visualization of the game. One of the students told me that he ever felt hard to understand several foreign terms when he played a game with a really low quality of visualization or animation.

I ever played a game with bad quality of visualization, and there was also no clue on how to say the new terms I found. I do realize that this condition made me struggling to comprehend, even in guessing the meaning of terms. (S1, Extract 6)

From the extract 6 , it can be said that a better meaningmaking is affected by the quality of visualization and the modes provided by the games. This is in line with the statement proposed by Suherdi (2015) which says that ICT in multimodal development supports better meaning-making.

The next stage is remembering. All students still engage quite well in this stage. This is probably because the vocabulary which they found in the game usually appears for several times, as shown in the extract 5 . Once the students have found out the meaning of a word, they have no reason to attend it anymore, and it will be forgotten easily (Rohmatillah, 2016). The last stage is consolidation and extension of meaning which means that the students can use the vocabulary in their daily life context and integrate the vocabulary as their stock of words. The students agreed that the games categorized in survival games are more related to daily life context than the MOBA game, as portrayed in the following extract. However, they realized that they do not engage in this stage. Most of their vocabulary was just used for gaming needs.

Yes, I think it is useful when we acquire new vocabulary. However, it will depend on the games. Most of the words are for gaming purposes, such as in MOBA. We, probably, will rarely use them. Games which relate to our daily life 
context will have more useful vocabularies for our daily life, and yes, in the survival game, I found more vocabularies than in MOBA game. (S2, Extract 7)

\section{Students' Experience in Gaining Motivation to Learn English through Online Games}

Motivation plays a crucial role in the learning process as it affects learning success. Moreover, there is a positive correlation between students' motivation and academic achievement (Solak \& Cakir, 2015). However, it is not an easy way to boost students' motivation in learning language, especially in learning vocabulary which has been seen as boring activity by many students. Thus, one of the ways to improve students' motivation is by using games. By playing games, the students are motivated to learn new vocabulary and new terms without feeling forced.

Every time I heard new sounds, I realized that I learned a new vocabulary. I love to imitate the sounds from the game and sometimes checking 'google translate' to know the exact meaning. As you know, we somehow, sometimes need to know the meaning to continue or to win the game. So, I will be willing to find out the meaning of new words or terms because I want to win the game or at least survive. (S2, Extract 8)

As shown in extract 8 , since the student wants to win the game and finish the mission, $\mathrm{S} 2$ is highly motivated. Moreover, S2 usually did some efforts such as look up the dictionary or search the meaning of the words through online to understand or at least to know the meaning of new vocabulary which they found in the game. However, they did not feel that those activities were forced. They did it to pursue their goal of playing the game. This internal motivation affects students' success in learning language, particularly in acquiring a second language (L2) vocabulary (Espinar-Redondo \& Ortega-Martin, 2015).

\section{CONCLUSION}

This study shows that games, particularly online games, are the potential to facilitate EFL students in acquiring second language (L2) vocabulary for several initial reasons. The first is that online game provides a subconscious learning experience in a particular context. By playing the game, the EFL students do not have any intention to learn so that they play for pleasure under a relaxing environment and in the particular context provided in the game. This condition supports students' learning experience. Secondly, online games provide various strategies to learn English so that EFL students acquire a second language (L2) vocabulary in many ways. The last reason is that online games motivate EFL students to learn new things, especially learning a new second language (L2) vocabulary. By playing the game, the EFL students were motivated to finish the mission and to win the game, so they did some efforts to achieve their goals. However, the study has its limitation: (1) only 4 EFL students were involved, (2) only two types of games were analyzed and (3) the data gained from only an online interview.
For an effective vocabulary teaching and learning, it is hoped that the teachers can adopt or adapt the principle of games, which were found in this study, in facilitating vocabulary learning: contextual, learning for pleasure, subconscious learning, relaxed environment, providing various ways to learn, motivating. If it is possible, the teachers are also suggested to provide special occasions for students to play online games together in the classroom to facilitate them in acquiring vocabulary. This is familiar with the term 'gamification'. However, the teachers need to make sure whether the game relates to the topic of learning or not, and whether the facilitation is possible or not. Further research on what kinds of vocabulary that the students learn from games and how it contributes to their language learning is needed to be investigated. A further discussion is also needed for a topic related to the aspects of language that the students learn through the game so that the other important aspects, besides vocabulary, will also get attention.

\section{REFERENCES}

Adriano, M. N. I. (2017). Distraction or instruction: the role of online interactive games in a child's second language acquisition. The Journal of Asia TEFL, 14(3), 573-580. doi: 10.18823/asiatefl.2017.14.3.15.573

Ashraf, H., Motlagh, F. G., \& Salami, M. (2014). The impact of online games on learning English vocabulary by Iranian (low-intermediate) EFL learners. Procedia-Social and Behavioral Sciences, 98, 286-291. doi: 10.1016/j.sbspro.2014.03.418

Asyiah, D. N. (2017). The vocabulary teaching and vocabulary learning: Perception, strategies, and influences on students' vocabulary mastery. Jurnal Bahasa Lingua Scientia, 9(2), 293-318. doi 10.21274/ls.2017.9.2.133-158

Cahyono, B. Y., \& Widiati, U. (2015). The teaching of EFL vocabulary in the Indonesian context: the state of the art. TEFLIN journal. 19(1), 1-17.

Chaochun, Y. \& Lian, C. (2005). Second Language Learning: Conscious or Unconscious?. CELEA Journal (Bimonthly). 28(4), 24-31.

Clarke, V., \& Braun, V. (2013). Teaching thematic analysis: Overcoming challenges and developing strategies for effective learning. The psychologist, 26(2), 120-123.

Cornillie, F., Thorne, S. L., \& Desmet, P. (2012). Digital games for language learning: From hype to insight? ReCALL Journal, 24(3), 243-256. doi: $10.1017 / \mathrm{s} 0958344012000134$

Epstein, A. S. (2007). The Intentional Teacher. Washington DC.

Espinar-Redondo, R., \& Ortega-Martin, J. L. (2015). Motivation: The road to successful learning. Profile Issues in Teachers Professional Development, 17(2), 125-136. doi: 10.15446/profile.v17n2.50563

Flores, J. F. F. (2015). Using gamification to enhance second language learning. Digital Education Review, (27), 32-54.

Folse, K. S. \& Briggs, S. J. (2004). Vocabulary myths: Applying second language research to classroom teaching. Ann Arbor: University of Michigan Press.

Gilford, L. R. (2016). The beliefs, perceptions, and strategies of vocabulary instruction in middle grades social studies: A phenomenological study.

Grauberg, W. (1997). The elements of foreign language teaching. Languages in Practice Vol. 7 UK: Multilingual Maters.

Huyen, N. T. T. \& Nga, K. T. T. (2003). Learning vocabulary through games. Asian EFL Journal, 5(4), 90-105.

Judger, N. (2016). The thematic analysis of interview data: An approach used to examine the influence of the market on curricular provision in Mongolian higher education institutions. Hillary Place Papers $\left(3^{\text {rd }}\right.$ Ed.), University of Leeds.

Merawati, M. V. J. (2003). Building on Students' Weaknesses to Practice Guessing Meaning from Contxt and Improve Reading Skills and Strategies. The 51st TEFLIN International Conference, Bandung. 
Nation, I. S. P. (2000). Learning vocabulary in another language. Cambridge: Cambridge University Press.

Read, J. (2000). Assessing Vocabulary (pp. 1-85). Cambridge: Cambridge University Press.

Renandya, W. A. \& Richards, J. C. (2002). Methodology in Language Teaching. New York: Cambridge University Press.

Rohmatillah, R. (2016). The effect of using the Jakarta Post newspaper articles in enhancing vocabulary of English for university students: An experimental research. English Education: Jurnal Tadris Bahasa Inggris, 9(2), 395-408.
Solak, E. \& Cakir, R. (2015). Exploring the effect of materials designed with augmented reality on language learners' vocabulary learning. The Journal of Educators Online, 12(2), 50-72.

Suherdi, D. (2015). Multimodal Pedagogy in TEFLIN Contexts. In The 62nd TEFLIN International Conference 2015 Proceedings: Teaching an Assessing L2 Learners in the 21st Century.

Yin, R. K. (2003). Case study research: Design and methods ( $3^{\text {rd }}$ Ed). Applied social research method series, Volume 5. Thousand Oaks, CA: SAGE Publication. 